COMMENT. The risk of recurrence of febrile seizures might be reduced by early administration of antipyretic drugs. Ibuprofen appears to be superior to acetominophen in antipyretic efficacy, but an anticonvulsant effect remains to be determined.

In laboratory studies of antipyretic agents, aspirin and acetophenetidin failed to retard the rate of temperature rise induced by radiotherm diathermy in animals, and aspirin in doses of $600 \mathrm{mg} / \mathrm{kg}$ lowered the threshold convulsive temperature and exacerbated the febrile seizure. Antipyretics in small doses may facilitate heat loss and relieve discomfort attending fever, but large doses may possibly exacerbate the tendency to febrile seizures. (Millichap JG. Febrile Convulsions, New York, Macmillan, 1968).

\title{
SERUM SODIUM AND FEBRILE CONVULSIONS
}

Serum sodium determinations were studied prospectively in 69 children with febrile convulsions followed in the Department of Paediatrics, Zuiderziekenhuis, Rotterdam, the Netherlands. Levels $<135 \mathrm{mmol} / 1$ were found in $52 \%$, and the mean level $(134.4 \mathrm{mmol} / \mathrm{l})$ was significantly lower compared to a group of children without fever $(140.6 \mathrm{mmol} / \mathrm{l})$ and a group with fever but no convulsions $(137.6 \mathrm{mmol} / \mathrm{l})$. Febrile seizure recurrence appeared to be correlated with a lowered serum sodium. (Hugen CAC et al. Serum sodium levels and probability of recurrent febrile convulsions. Eur I Pediatr May 1995;154:403-405). (Respond: Dr CAC Hugen, Department of Paediatrics, Zuiderziekenhuis, Groene Hilledijk 315. NL-3075 EA Rotterdam, the Netherlands).

COMMENT. The authors acknowledge previous demonstration of a lowered threshold to febrile convulsions in animals with hyponatremia (Millichap JG. Neurology 1960;10:312-321), but overlook the previous clinical report of hyponatremia $(130 \mathrm{mEg} / 1$ or lower) in $4(24 \%)$ of 17 children with febrile seizures, and serum sodium of $131-138 \mathrm{mEq} / 1$ in the remaining 13 patients examined. (Millichap JG et al. Studies in febrile seizures. V. Clinical and EEG study in unselected patients. Neurology 1960;10:643-653; idem. Febrile Convulsions, New York, Macmillan, 1968). Serum sodium determination is important in a child with a febrile convulsion.

\section{ATTENTION-DEFICIT DISORDERS}

\section{BUPROPION v. METHYLPHENIDATE IN ADHD}

The efficacy of bupropion and methylphenidate in the treatment of ADHD was compared in a double-blind, crossover study of 15 patients ( 7 to 17 years of age) at the University of Iowa, Iowa City. Methylphenidate titrated from 0.4 to $1.3 \mathrm{mg} / \mathrm{kg}$ per day (mean $0.7 \mathrm{mg} / \mathrm{kg} / \mathrm{d}$ ) and bupropion 1.4 to 5.7 $\mathrm{mg} / \mathrm{kg} / \mathrm{d}$ (mean $3.3 \mathrm{mg} / \mathrm{kg} / \mathrm{d}$ ) over a 6 week period were followed by a 2 week wash out period. Both drugs were effective in the treatment of ADHD, but rating scales trended in favor of methylphenidate. (Barrickman LL, Perry PJ et al. Bupropion versus methylphenidate in the treatment of attention-deficit hyperactivity disorder. I Am Acad Child Adolesc Psychiatry May 1995;34:649657). (Reprints: Dr Perry, 2271 Quadrangle, University of Iowa, Iowa City, IA 52242).

COMMENT. Side effects were minor with either drug in this study. 